\title{
Mengoptimalkan Kemampuan Berbahasa Anak Usia Dini Melalui Metode Bercerita
}

\author{
Firdausi Nuzula Apriliyana \\ elnuzula23@gmail.com \\ Pendidikan Guru Pendidikan Anak Usia Dini \\ Fakultas Keguruan dan Ilmu Pendidikan \\ Universitas PGRI Ronggolawe Tuban
}

\begin{abstract}
Abstrak
Kemampuan berbahasa anak dalam kegiatan menyimak dan berbicara belum optimal, perbendaharaan kosa kata anak masih terbatas, sehingga anak dalam menyampaikan ide, menjawab pertanyaan, mengulang kembali cerita, dan bercerita pengalamannya masih belum tercapai sesuai harapan. Tujuan pelaksanaan penelitian ini untuk menganalisis pengaruh metode bercerita terhadap perkembangan kemampuan berbahasa anak usia dini. Jenis penelitiannya ini adalah penelitian eksperimen dengan bentuk rancangan nonequivalent control group design. Pelaksanaan penelitian ini di KB 'Aisyiyah Mentari Tuban dengan jumlah subjek 32 anak. Jumlah subjek tersebut dibagi menjadi 2 kelompok yaitu kelompok kontrol dan eksperimen sebagai perbandingan perkembangan kemampuan berbahasa. Pengumpulan data penelitian menggunakan teknik observasi dan dokumentasi. Uji validitas dengan pearson correlation dan uji reliabilitas dengan Cronbach Alpha dilaksanakan terlebih dahulu kemudian menganalisis data dengan uji t. Hasil penelitian ini dibuktikan dengan metode bercerita bisa mengoptimalkan kemampuan berbahasa anak usia dini. Perhitungan dengan uji $t$ hitung untuk semua indikator $>t$ kritis 1.7530 , maka dapat disimpulkan bahwa $\mathrm{HO}$ ditolak, $\mathrm{H} 1$ diterima. Artinya ada pengaruh metode bercerita untuk semua indikator terhadap kemampuan berbahasa anak. Saran bagi pendidik dan lembaga PAUD agar dapat mengimplementasikan metode bercerita sebagai metode yang dapat menstimulasi kemampuan berbahasa anak.
\end{abstract}

Kata Kunci: Metode Bercerita, Kemampuan Berbahasa

\begin{abstract}
Children's language skills in listening and speaking activities are not optimal, children's vocabulary is still limited, so that children in conveying ideas, answering questions, repeating stories and telling stories about their experiences have not been achieved as expected. The purpose of this research is to analyze the effect of storytelling methods on the development of language skills in early childhood. This type of research is an experimental study with a nonequivalent control group design. The research was carried out in KB 'Aisyiyah Mentari Tuban with 32 children as subjects. The number of subjects was divided into 2 groups, namely the control and experimental groups as a comparison of the development of language skills. Collecting research data using observation and documentation techniques. The validity test with the Pearson correlation and the reliability test with Cronbach Alpha were carried out first then analyzed the data with the t test. The results of this study were proven by using the storytelling method to optimize early childhood language skills. Calculation using the t-test for all indicators $>t$ critical 1.7530 , it can be concluded that $\mathrm{HO}$ is rejected, $\mathrm{H} 1$ is accepted. This means that there is an effect of storytelling methods for all indicators on children's language skills. Suggestions for
\end{abstract}


Jurnal PINUS: Jurnal Penelitian Inovasi Pembelajaran, 6 (1), 2020, Firdausi Nuzula Apriliyana

educators and PAUD institutions to implement storytelling methods as a method that can stimulate children's language skills.

Keywords: Storytelling Method, Language Ability

\section{PENDAHULUAN}

Hakikatnya pendidikan diberikan sejak usia dini untuk memfasilitasi perkembangan anak. Perkembangan anak merupakan kemampuan anak dalam mengenal diri dan lingkungan sekitar serta peningkatan kesadaran seiring dengan pertumbuhan fisik yang telah dialami oleh anak. Anak usia dini memiliki berbagai kemampuan untuk berkembang, salah satunya adalah perkembangan bahasa.

Menurut Sapir dalam (Hartati, 2018) bahwa Bahasa merupakan cara khas seseorang (bukan bersifat naluri) dalam mengkomunikasikan ide atau kemauannya dengan menggunakan simbol secara sengaja. Sedangkan bentuk komunikasi berupa ucapan ataupun tulisan dengan dasar sistem simbol merupakan makna dari Bahasa (J. Santrock, 2010). Dari pendapat tersebut bisa disimpulkan bahwa bahasa adalah cara khas seseorang dalam melakukan komunikasi untuk menyampaikan ide atau kemauannya baik berupa lisan ataupun tertulis yang didasarkan pada simbol.

Pengembangan berbahasa terjadi saat memahami dan mengkomunikasikan melalui kata, ujaran dan tulisan. Pengembangan berbahasa lebih diarahkan agar anak mampu mengerti dan mengartikan setiap kata serta mampu menyampaikan secara utuh kepada orang lain. Hal ini sejalan dengan Nasional
(2010). bahwa pengembangan berbahasa mengarah pada anak agar semua anak bisa menggunakan kata-kata dari kemampuannya dalam menggunakan dan mengekspresikan pemikiran anak.

Menurut Bachri (2005) bahwa pengembangan berbahasa mempunyai 2 tujuan yakni mendengar dan berbicara, membaca dan menulis. Sedangkan Nasional (2010) menyampaikan bahwa pengembangan bahasa anak lebih terfokus pada mendengar, berbicara, dan membaca permulaan.

Lingkungan yang akan memperbanyak bahasa anak sehingga peran penting dari orangtua serta pendidik saat mempersiapkan anak dan lingkungan sangat diharapkan untuk pemerolehan bahasa anak dapat meningkat dengan optimal. Hal tersebut sependapat dengan Musfiroh (2008) menyampaikan jika dukungan dan keterdidikan dari lingkungan dan kematangan sel korteks sangat mempengaruhi pada perkembangan bahasa anak. perkembangan bahasa itu tergantung pada dukungan dan keterdidikan dari lingkungan dan kematangan sel korteks. Sedangkan Tamis-LeMonda, Bordnstein \& Baumwell dalam (J. Santrock, 2010) menyampaikan bahwa Lingkungan berperan besar dalam perkembangan Bahasa utamanya dalam penguasaan kosa kata. Pendapat Chomsky dalam (J. Santrock, 2010) bahwa pada waktu dan 
Jurnal PINUS: Jurnal Penelitian Inovasi Pembelajaran, 6 (1), 2020, Firdausi Nuzula Apriliyana

cara tertentulah kecenderungan manusia dalam mempelajari bahasa.

Bahasa harus digunakan oleh anak saat berkomunikasi dengan orang lain (J. W. Santrock, 2007). Sehingga dapat dikatakan bahwa bahasa merupakan simbol penting dalam komunikasi. Dapat diartikan bahwa bahasa berbanding lurus dengan komunikasi, apabila anak memliki perkembangan berbahasa yang baik, maka anak-anak juga memiliki kemampuan berkomunikasi yang baik.

Bahasa adalah alat komunikasi. Menurut Nasional (2010) bahwa bahasa berfungsi sebagai alat komunikasi terdiri dari 4 ketrampilan yaitu (1) ketrampilan berbahasa (dalam berperilaku saat menyapa, memperkenalkan diri, bertanya, menyatakan pendapat, dll), (2) ketrampilan mendengar (dalam berperilaku saat mendengarkan perintah, pertanyaan, pendapat, ataupun cerita dari orang lain), (3) ketrampilan berbicara (dalam perilaku saat mengembangkan ketrampilan dalam bertanya, menyiapkan kegiatan yang dilakukan, dll), dan (4) ketrampilan membaca yang melibatkan unsur visual dan auditif. Sedangkan fungsi bahasa dalam pembelajaran menurut (Hartati, 2018) adalah bahasa dapat membantu anak mengenal perilaku, risiko, konsekuensi, dan sebab akibat, bahasa dapat menjadi terapi perbaikan perilaku anak dan bahasa dapat membangun kesadaran tentang diri, orang lain dan lingkungan.

Menurut Peraturan Menteri Pendidikan dan Kebudayaan RI Nomor 137 tahun 2014 tentang Standar Nasional PAUD yaitu capaian perkembangan bahasa anak usia 3-4 tahun dengan ciri kemampuan anak dalam memahami bahasa yaitu berpura-pura membaca cerita bergambar yang ada di buku dengan kalimat sendiri dan kemampuan anak untuk mengucapkan bahasa yaitu mulai mau menceritakan pengalaman anak dengan cerita sederhana.

Berdasarkan pedoman kurikulum tersebut, metode untuk mengembangkan kemampuan anak dalam berbahasa yaitu metode bercerita. Hal ini di dasarkan pada pendapat Depdiknas dalam (Musfiroh, 2008) bahwa kurikulum berbasis kompetensi merupakan materi yang digunakan untuk mengembangkan kompetensi dasar berkomunikasi dalam kelancaran bercerita dan penguasaan ;kosa kata dengan menggunakan cerita. Kurikulum berbasis kompetensi memanfaatkan metode yang tepat dan kontekstual yang dalam pelaksanaan pembelajaran terintegrasi dengan tiga bidang pengembangan yaitu pengembangan nilai agama dan moral, sosial-emosional, serta kemampuan dasar (bahasa, fisik, kognitif, dan akademik) adalah metode bercerita.

Kemampuan untuk menceritakan pengalaman bagi anak usia 3-4 tahun tidaklah diperoleh secara langsung, namun perlu adanya stimulasi secara bertahap. Kosakata kata yang dimiliki oleh anak haruslah cukup untuk membantu memudahkan mereka dalam menyampaikan pengalamannya melalui cerita sederhana.

Pada umumnya memiliki perbendaharaan kosa kata saja dapat mendukung anak dalam menceritakan pengalaman, namun tidak semua anak 
Jurnal PINUS: Jurnal Penelitian Inovasi Pembelajaran, 6 (1), 2020, Firdausi Nuzula Apriliyana

dapat menyampaikan secara langsung ide atau pengalaman yang telah anak miliki karena hal tersebut berhubungan dengan kemampuan berpikir anak. Sehingga membutuhkan latihan secara terus menerus dan pembiasaan. Kesulitan dalam menceritakan pengalaman juga dapat berdampak pada kemampuan anak saat mengungkapkan gagasan/ide kepada orang lain. Hal ini dapat dikatakan sebagai hambatan dalam berkomunikasi.

Pada umumnya anak usia 3-4 tahun mempunyai kendala untuk menjawab pertanyaan secara langsung dan menceritakan pengalaman sederhana yang telah dimiliki anak, oleh karena itu dibutuhkan cara untuk membantu anak dalam menyampaikan ide atau pengalaman agar dipahami oleh orang lain sebagai lawan bicaranya, yaitu melalui metode bercerita.

Menurut Moeslichatoen (2004) metode bercerita yakni cara yang digunakan dengan menyampaikan cerita pada anak secara lisan untuk memberikan pengalaman belajar. Sedangkan (Bachri, 2005) mengungkapkan bercerita merupakan kegiatan menyampaikan sesuatu untuk membagikan ide ataupun pengalaman pada orang lain dengan mengisahkan sebuah kejadian secara lisan dan dalam pembelajaran di PAUD bercerita menjadi usaha untuk mengembangkan potensi yang dimiliki anak dalam kemampuan berbahasa melalui kegiatan mendengarkan dan menuturkan kembali dengan tujuan melatih ketrampilan menyimak dan berbicara anak untuk menyampaikan ide secara lisan.

Bercerita menjadi hal penting untuk PAUD. Bercerita memiliki aneka manfaat yaitu (1) anak mampu mengembangkan kosa kata, kemampuan berbicara, (3) dalam situasi menyenangkan dapat mengekspresikan cerita sesuai karakteristik tokoh, serta (4) melatih keberanian anak untuk bercerita di depan (Rahayu, 2013). Sejalan juga dengan pendapat Moeslichatoen (2004) bahwa manfaat bercerita adalah (1) anak mampu menyampaikan nilai budaya, sosial, juga keagamaan, meningkatkan semangat bekerja, (3) mengembangkan fantasi, kognitif dan bahasa anak.

Bercerita bagi anak usia dini merupakan sesuatu yang sangat menyenangkan. Bercerita pada anak usia dini dapat menggunakan berbagai macam cara, antara lain bercerita langsung, bercerita menggunakan buku cerita, mendongeng, bercerita menggunakan media boneka atau papan flannel, bercerita melalui main peran, melalui lagu dan rekaman audio (Moeslichatoen, 2004).

Namun pada kenyataannya kegiatan menyimak dan berbicara anak belum optimal, perbendaharaan kosa kata anak masih terbatas, sehingga anak-anak dalam menyampaikan ide, menjawab pertanyaan, mengulang kembali cerita dan bercerita pengalamannya masih belum tercapai sesuai harapan. Hal ini berdasarkan hasil observasi pada anak Kelompok Bermain 'Aisyiyah Mentari Kecamatan Tuban Kabupaten Tuban, yang menunjukkan bahwa dalam proses pembelajaran jarang dilakukan kegiatan bercerita dan capaian perkembangan kemampuan bahasa anak dalam 
Jurnal PINUS: Jurnal Penelitian Inovasi Pembelajaran, 6 (1), 2020, Firdausi Nuzula Apriliyana

pengembangan kosa kata untuk menyampaikan ide, menjawab pertanyaan dari guru, mengulang kembali cerita serta bercerita pengalaman anak yang sudah berkembang sesuai harapan hanya 12 anak yakni $39 \%$ dari jumlah keseluruhan 32 anak.

Berdasarkan deskripsi di atas, peneliti melaksanakan penelitian berjudul "Mengoptimalkan Kemampuan Berbahasa Anak Usia Dini melalui Metode Bercerita" yang dilaksanakan di Kelompok Bermain 'Aisyiyah Mentari Kecamatan Tuban Kabupaten Tuban. Alasan peneliti melaksanakan penelitian di lembaga tersebut karena perkembangan bahasa anak-anak masih kurang optimal dan jarang dilakukannya penelitian yang berkaitan perkembangan Bahasa di KB 'Aisyiyah Mentari Kecamatan Tuban Kabupaten Tuban. Tujuan penelitian ini untuk menganalisis pengaruh metode bercerita terhadap perkembangan kemampuan berbahasa anak usia dini.

\section{METODE}

Penelitian ini dengan jenis penelitian kuantitatif, yakni penelitian berupa penggambaran data yang bentuk angka yang bersifat kuantitatif, dapat digunakan untuk melihat kondisi berupa populasi dan masa yang akan datang. Metode penelitian ini dilaksanakan dengan menentukan populasi kemudian mengambil sampel secara random. Uji hipotesis dilakukan dengan menganalisis data yang didasarkan pada instrumen penelitian secara kuantitatif (Sugiyono, 2009).

Rancangan penelitian ini menggunakan penelitian eksperimen yang dilaksanakan terhadap data yang belum ada pada variabel sehingga diperlukan proses manipulasi dengan memberi perlakukan tertentu pada subjek penelitian yang kemudian dampaknya akan diamati dan diukur. Menurut Riyanto (2001), penelitian eksperimen yakni penelitian yang sistematis, logis, dan teliti di dalam melakukan kontrol terhadap kondisi.

Rancangan penelitian berupa pola pelaksanaan penelitian Quasi Experimental, jenis Non equivalent Control Group Design dengan kelompok dibagi menjadi 2 yakni kelompok kontrol dan kelompok eksperimen sebagai perbandingan perkembangan kemampuan berbahasa. Langkah awal dengan melakukan pretest pada dua kelompok tersebut guna mengetahui kondisi awal. Kemudian peneliti tidak memberikan perlakukan pada kelompok kontrol dan memberi perlakuan kelompok eksperimen berupa metode bercerita. Sesudah itu, dilaksanakan post test dengan treatment guna melihat kemampuan akhir anak dalam menceritakan pengalaman.

Pelaksanaan penelitian pada JuliDesember 2019. Subjek penelitiannya adalah peserta didik Kelompok Bermain 'Aisyiyah Mentari Kecamatan Tuban Kabupaten Tuban kelompok A-1 dan A2 dengan jumlah 32 anak terbagi 2 yaitu kelompok kontrol 16 anak dan 16 anak pada kelompok eksperimen. Pengumpulan data dalam penelitian ini dengan teknik observasi serta dokumentasi. Pendapat Riyanto (2001) Observasi adalah metode yang dipakai 
Jurnal PINUS: Jurnal Penelitian Inovasi Pembelajaran, 6 (1), 2020, Firdausi Nuzula Apriliyana

saat pengumpulan data dengan pengamatan pada obyek yang diteliti. Teknik observasi tersebut digunakan untuk mengumpulkan data tentang variabel penelitian yaitu metode bercerita yang mengoptimalkan kemampuan berbahasa anak yang berkaitan dengan proses belajar dengan bermain pada anak. Indikator yang diamati terhadap kemampuan berbahasa dari kurikulum yang ada dalam Permendikbud RI No. 137 tahun 2014 tentang Standar Nasional PAUD, yaitu pada capaian perkembangan bahasa anak usia 3-4 tahun, yaitu : berpura-pura membaca cerita bergambar dalam buku dengan kata-kata sendiri dan menceritakan pengalaman yang dialami dengan cerita sederhana, indikatornya (A) anak mampu membaca gambar dari buku bergambar dengan kalimat anak sendiri, (B) anak mampu bercerita dengan bahasa sendiri menggunakan media, (C) anak mampu bercerita kembali cerita yang didengar dari guru (D) anak mampu menceritakan pengalaman sederhana yang pernah dialami dengan bahasa anak sendiri. Pada penelitian ini dokumen yang digunakan adalah RPPM, RPPH yang dilengkapi dengan langkah-langkah pembelajaran sesuai perencanaan dan yang akan dilaksanakan, foto kegiatan dan hasil pengamatan pada semua kegiatan mulai awal sampai akhir penelitian. Nilai diberikan berdasarkan pedoman penilaian yaitu belum berkembang (1), mulai berkembang (2), berkembang sesuai harapan (3) dan berkembang sangat baik (4). Kemampuan berbahasa diukur sebelum dan setelah perlakuan. Pengumpulan data berupa cheklist yang digabung dengan pedoman observasi dengan rating scale 1-4.

Penelitian ini menggunakan analisis secara inferesial statitistik dengan statistik parametris. Menurut Bandung \& Fathoni (2012) bahwa penelitian ini dengan data analisis berupa data interval yakni dalam bentuk kategori yang dapat dikuantitatifkan dan memiliki urutan tingkatan. Statistik parametris penelitian ini, guna mengetahui normalitas dan homogenitas data penelitian ini dengan uji hipotesis yang dilaksanakan melalui uji prasyarat analisis. Uji hipotesis penelitian ini menggunakan uji t.

Uji validitas dan reliabilitas dilaksanakan terlebih dahulu sebelum menganalisis data. Untuk mengukur kevalidan suatu kuesioner menggunakan uji validitas (Ghozali, 2001). Membandingkan nilai $\mathrm{r}$ hitung (nilai hitung Corrected item-Total Correlation pada output Cronbach alpha) dengan nilai $r$ tabel untuk degree of freedom (df) $=\mathrm{n}-2$ ( $\mathrm{n}$ adalah jumlah sampel) merupakan cara yang dapat dilakukan untuk uji signifikansi. Sedangkan uji realibilitas dilaksanakan pada suatu pertanyaan yang dinyatakan valid. Uji ini dimanfaatkan untuk mengukur suatu kuesioner berupa indikator dari variabel (Ghozali, 2001). Jika jawaban seseorang pada pertanyaan itu konsisten / stabil dari waktu ke waktu maka suatu kuesioner tersebut disebut reliabel.

\section{HASIL DAN PEMBAHASAN}

Uji validitas dengan metode pearson correlation yaitu dengan mengkorelasikan antara skor tiap item dengan skor total (Priyatno, 2010). Uji 
Jurnal PINUS: Jurnal Penelitian Inovasi Pembelajaran, 6 (1), 2020, Firdausi Nuzula Apriliyana

validitas penelitian ini dengan jumlah sampel(n) adalah 32 dan tingkat signifikansi 0.05. Dengan demikian $\mathrm{r}$ tabel pada penelitian ini adalah : $\mathrm{r}(0.05 ; 30-2=30)=0.3494$. Jika $\mathrm{r}$ hitung lebih besar daripada $r$ tabel dan berkorelasi positif maka pertanyaan tersebut valid. Atau dengan kata lain item pertanyaan dikatakan valid apabila skor item pertanyaan memiliki korelasi yang positif dan signifikan dengan skor total variabel. Berikut tabel hasil uji validitasnya.

\begin{tabular}{|c|c|c|c|c|}
\hline \multicolumn{5}{|c|}{ Item-Total Statistics } \\
\hline & & Scale & & \\
\hline & $\begin{array}{c}\text { Scale } \\
\text { Mean if } \\
\text { Item } \\
\text { Deleted }\end{array}$ & $\begin{array}{c}\text { Varianc } \\
\mathrm{e} \text { if } \\
\text { Item } \\
\text { Deleted }\end{array}$ & $\begin{array}{c}\text { Correct } \\
\text { ed Item- } \\
\text { Total } \\
\text { Correlat } \\
\text { ion }\end{array}$ & $\begin{array}{c}\text { Cronba } \\
\text { ch's } \\
\text { Alpha if } \\
\text { Item } \\
\text { Deleted }\end{array}$ \\
\hline $\begin{array}{c}\text { Bhs } \\
1\end{array}$ & 12.8667 & 1.706 & .699 & .879 \\
\hline $\begin{array}{c}\text { Bhs } \\
2\end{array}$ & 12.7667 & 1.771 & .789 & .835 \\
\hline $\begin{array}{c}\text { Bhs } \\
3\end{array}$ & 11.0667 & 5.099 & .729 & .859 \\
\hline $\begin{array}{c}\text { Bhs } \\
4\end{array}$ & 11.9333 & 2.616 & .669 & .953 \\
\hline
\end{tabular}

Hasil Uji validitas menunjukkan bahwa seluruh item pertanyaan dalam kuesioner mempunyai item-total correlation > 0.3494 maka pertanyaan tersebut valid.

Kemudian dilaksanakan uji reliabilitas. Menurut Ghozali (2001) jika memiliki Cronbach Alpha>0.6 maka suatu variabel disebut reliabel.

Hasil yang diperoleh dari perhitungan nilai koefisien reliabilitas untuk instrument penelitian yang digunakan adalah :

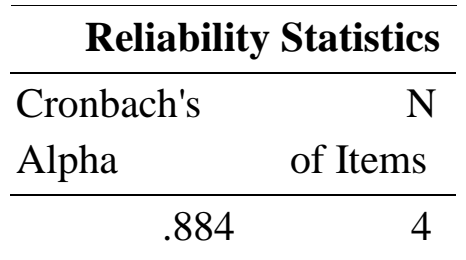

Berdasarkan pengujian reliabilitas instrument penelitian, hasil yang didapat adalah 0.884 , karena memperoleh nilai koefisien reliabilitas > 0.60 maka instrument penelitian tersebut dinyatakan reliabel.

Setelah dilakukan uji reliabilitas dan validitas dengan hasil reliabel dan valid, maka selanjutnya dilakukan uji prasyarat analisis.

Hasil uji prasyarat pada uji normalitas berdasarkan nilai Kolmogorov Smirnov memiliki signifikansi dengan 0,242 ( $\operatorname{sig} \geq 0,05$ ), baik dari hasil sebelum perlakuan maupun sesudah perlakuan pada kelompok eksperimen maupun kelompok kontrol, sehingga dapat diartikan bahwa hasil uji normalitas data kelompok eksperimen maupun kelompok kontrol tersebut berditribusi normal.

Setelah menganalisis uji prasyarat kemudian dilakukan uji hipotesis. Pengambilan keputusan menggunakan angka pembanding $\mathrm{t}$ kritis dengan kriteria sebagai berikut:

a. Jika t hitung > t kritis H0 ditolak; H1 diterima

b. Jika t hitung < t table H0 diterima; H1 ditolak

Hipotesis yang digunakan sebagai berikut: 
Jurnal PINUS: Jurnal Penelitian Inovasi Pembelajaran, 6 (1), 2020, Firdausi Nuzula Apriliyana

HO : tidak ada pengaruh antara metode bercerita terhadap kemampuan berbahasa anak.

H1 : Ada hubungan antara metode bercerita terhadap kemampuan berbahasa anak

Nilai $\mathrm{T}$ kritis yang digunakan adalah sebesar 1.7530 dengan menggunakan ketentuan $\alpha=0,05$ dan derajat kebebasan 15.

Berdasarkan hasil perhitungan uji-t diperoleh perhitungan $t$ hitung dan nilai signifikan untuk kelompok metode eksperimen sebagai berikut :

\begin{tabular}{ccccc}
\hline Kelompok & \multicolumn{4}{c}{ Nilai $\mathrm{t}-$ hitung Indikator } \\
\cline { 2 - 5 } & $\mathrm{A}$ & $\mathrm{B}$ & $\mathrm{C}$ & $\mathrm{D}$ \\
\hline Eksperimen & -1.9792 & -1.9186 & -2.3419 & -1.7770 \\
\hline
\end{tabular}

\begin{tabular}{ccccc}
\hline Kelompok & \multicolumn{4}{c}{ Nilai sig Indikator } \\
\cline { 2 - 5 } & $\mathrm{A}$ & $\mathrm{B}$ & $\mathrm{C}$ & $\mathrm{D}$ \\
\hline Eksperimen & 0.0332 & 0.0371 & 0.0167 & 0.0479 \\
\hline
\end{tabular}

Dari tabel di atas diketahui bahwa :

- nilai t hitung untuk indikator A adalah sebesar 1.9792, sehingga karena $t$ hitung $1.9792>\mathrm{t}$ kritis 1.7530, maka dapat disimpulkan bahwa $\mathrm{H} 0$ ditolak, H1 diterima. Artinya ada pengaruh metode bercerita indikator A terhadap kemampuan berbahasa anak.

- nilai t hitung untuk indikator B adalah sebesar 1.9186, sehingga karena $t$ hitung $1.9186>\mathrm{t}$ kritis 1.7530, maka dapat disimpulkan bahwa H0 ditolak, H1 diterima. Artinya ada pengaruh metode bercerita indikator B terhadap kemampuan berbahasa anak.

- nilai t hitung untuk indikator C adalah sebesar 2.3419, sehingga karena $\mathrm{t}$ hitung $2.3419>\mathrm{t}$ kritis 1.7530, maka dapat disimpulkan bahwa H0 ditolak, H1 diterima. Artinya ada pengaruh metode bercerita indikator $\mathrm{C}$ terhadap kemampuan berbahasa anak.

- nilai t hitung untuk indikator D adalah sebesar 1.7770, sehingga karena $t$ hitung $1.7770>\mathrm{t}$ kritis 1.7530 , maka dapat disimpulkan bahwa H0 ditolak, H1 diterima. Artinya ada pengaruh metode bercerita indikator D terhadap kemampuan berbahasa anak.

Berdasarkan tabel di atas, nilai signifikansi untuk indicator A,B,C, dan D $<0.05$, sehingga dapat disimpulkan bahwa H0 ditolak dan $\mathrm{Hi}$ diterima. Artinya ada pengaruh metode bercerita dengan indikator A,B,C dan D terhadap kemampuan berbahasa anak.

Perbandingan rata-rata nilai / capaian indikator dari kemampuan berbahasa antara Kelompok Kontrol dengan Kelompok Eksperimen :

\begin{tabular}{crr}
\hline Kelompok & \multicolumn{2}{c}{ Rata-Rata Indikator } \\
\cline { 2 - 3 } & $\begin{array}{c}\text { Sebelum } \\
\text { Perlakuan }\end{array}$ & $\begin{array}{c}\text { Setelah } \\
\text { Perlakuan }\end{array}$ \\
\hline Kontrol & 2.17 & 2.47 \\
\hline Eksperimen & 2.20 & 3.23 \\
\hline
\end{tabular}

Hasil di atas menunjukkan bahwa rata-rata kemampuan berbahasa anak sebelum perlakuan hampir sama yaitu 2.17 dan 2.20 namun hasil akhir dari kelompok tersebut terdapat perbedaan. Perbedaan tersebut dapat dilihat dari kedua kelompok yang menunjukkan bahwa hasil rata-rata setelah perlakuan lebih besar daripada sebelum perlakuan. Sehingga memberi perlakuan pada kelompok eksperimen dengan metode bercerita pada perkembangan kemampuan berbahasa anak sangat berpengaruh daripada kelompok kontrol. 
Jurnal PINUS: Jurnal Penelitian Inovasi Pembelajaran, 6 (1), 2020, Firdausi Nuzula Apriliyana

Hasil penelitian dan uji hipotesis menunjukkan bahwa KBM dengan metode bercerita berpengaruh pada perkembangan kemampuan berbahasa anak.

Berdasarkan hasil tersebut menunjukkan bahwa setelah mengikuti pembelajaran dengan metode bercerita memiliki pengaruh pada capaian perkembangan kemampuan berbahasa anak dengan optimal sebagaimana penelitian terdahulu yang dilakukan oleh Saribu \& Hidayah (2019) dengan judul meningkatkan kemampuan berbahasa anak melalui metode cerita menyatakan bahwa kemampuan berbahasa anak dapat meningkat melalui metode bercerita. Begitu juga penelitian yang dilakukan oleh Utami \& Khusnal (2014) dengan judul pengaruh metode bercerita dengan gambar terhadap perkembangan bahasa anak usia 3-5 tahun di PAUD Sariharjo Ngaglik Sleman yang menyatakan bahwa metode bercerita berpengaruh secara signifikan terhadap kemampuan bahasa anak.

Hasil penelitian tersebut menyimpulkan bahwa metode bercerita bisa mengoptimalkan kemampuan berbahasa anak. Kegiatan yang sangat sesuai untuk mengembangkan kemampuan berbahasa anak adalah beraktivitas kegiatan bercerita dengan bahasa anak sendiri baik menggunakan buku bergambar, buku bercerita ataupun boneka, menceritakan kembali cerita sederhana dan bercerita pengalaman yang pernah dialami oleh anak adalah. Hal ini sesuai dengan pendapat Moeslichatoen (2004) bahwa metode bercerita adalah cara untuk memberikan pengalaman belajar yang menyampaikan sebuah cerita dengan ucapan pada anak. Senada juga dengan Depdiknas dalam (Musfiroh, 2008) bahwa untuk pengembangan kompetensi dasar berkomunikasi dalam kelancaran bercerita dan penguasaan kosa kata pada kurikulum berlandaskan kompetensi dengan menggunakan cerita. Kurikulum berlandaskan kompetensi itu memanfaatkan metode yang tepat dan kontekstual dalam pelaksanaan pembelajaran terintegrasi dengan tiga bidang pengembangan bahasa, kognitif, fisik dan akademik adalah metode bercerita.

\section{KESIMPULAN}

Hasil penelitian dan pembahasan tersebut, bisa disimpulkan bahwa metode bercerita bisa mempengaruhi perkembangan kemampuan berbahasa anak usia dini. Adanya perbedaan dari hasil yang dicapai oleh kelompok kontrol dan kelompok eksperimen dari rata-rata nilai setelah perlakuan hasilnya lebih besar dari pada hasil sebelum perlakuan. Berdasarkan perhitungan dengan uji $\mathrm{t}$ hitung untuk semua indikator $>\mathrm{t}$ kritis 1.7530, maka dapat disimpulkan bahwa H0 ditolak, H1 diterima. Artinya ada pengaruh metode bercerita untuk semua indikator terhadap kemampuan berbahasa anak.

Terkait hasil penelitian ini, saran yang bisa diberikan yakni kemampuan berbahasa anak dapat berkembang dengan optimal jika pendidik mengembangkan kemampuan berbahasa anak menggunakan metode bercerita baik bercerita secara langsung ataupun menggunakan media. 
Jurnal PINUS: Jurnal Penelitian Inovasi Pembelajaran, 6 (1), 2020, Firdausi Nuzula Apriliyana

\section{DAFTAR RUJUKAN}

Bachri, S. B. (2005). Pengembangan Kegiatan Bercerita, Teknik dan Prosedurnya. Jakarta: Depdikbud.

Bandung, R. D., \& Fathoni, A. A. (2012). Alfabeta. Sujarweni, V Dan Poly Endrayanto.

Ghozali, I. (2001). Aplikasi Analisis Multivariate dengan Program SPSS. Badan Penerbit Universitas Diponegoro.

Hartati, M. (2018). Pengaruh Penerapan Metode BCCT (Beyond Center And Circle Time) terhadap Kemampuan Membaca (Studi di PAUD Sayang Bunda Bengkulu Tengah). Annizom, 3(3).

Moeslichatoen, R. (2004). Metode Pengajaran Di Taman Kanakkanak, cet ke-2 (Jakarta: PT Asdi Mahasatya.

Musfiroh, T. (2008). Memilih, menyusun, dan menyajikan cerita untuk anak usia dini. Yogyakarta: Tiara Wacana.

Nasional, D. P. (2010). Pedoman Pembelajaran Bidang Pengembangan Bahasa di Taman Kanak-kanak. Jakarta: Depdiknas.

Priyatno, D. (2010). Teknik Mudah dan Cepat Melakukan Analisis Data Penelitian dengan SPSS. Gava Media.
Rahayu, A. Y. (2013). Menumbuhkan kepercayaan diri melalui kegiatan bercerita. Jakarta: Indeks.

Riduwan, A. (2009). Rumus dan Data dalam Aplikasi Statistika (Cetakan Ketiga) Bandung: $C V$. Alfabeta.

Riyanto, Y. (2001). Metodologi penelitian pendidikan. Surabaya: Sic, 318 .

Santrock, J. (2010). W.(2011). Psikologi Pendidikan (Edisi Kedua). Jakarta: Kencana Prenada Media Group.

Santrock, J. W. (2007). Perkembangan anak. Jakarta: Erlangga, 1(2), 3.

Saribu, A., \& Hidayah, A. N. (2019). Meningkatkan Kemampuan Berbahasa Anak melalui Metode Bercerita. JURNAL RISET GOLDEN AGE PAUD UHO, 2(1), 6-14.

Sugiyono. (2009). Metode Penelitian Kuantitatif, Kualitatif dan $R \& D$. Alfabeta.

Utami, S. W., \& Khusnal, E. (2014). Pengaruh Metode Bercerita Dengan Gambar Terhadap Perkembangan Bahasa Anak Usia 3-5 Tahun Di Paud Sariharjo Ngaglik Sleman. STIKES'Aisyiyah Yogyakarta. 